\title{
Determinants of Capital Structure: Evidence from Tunisian Listed
} Firms

\author{
Mouna Zerriaa ${ }^{1} \&$ Hedi Noubbigh ${ }^{1}$ \\ ${ }^{1}$ Institute of High Commercial Studies of Carthage (IHEC Carthage), Tunisia \\ Correspondence: Mouna Zerriaa, Institute of High Commercial Studies of Carthage (IHEC Carthage), Tunisia. \\ E-mail: mouna.zerriaa@gmail.com
}

Received: June 16, 2015

Accepted: July 8, 2015

Online Published: August 22, 2015

doi:10.5539/ijbm.v10n9p121

URL: http://dx.doi.org/10.5539/ijbm.v10n9p121

\begin{abstract}
This paper investigates the determinants of capital structure based on a panel of 32 non-financial companies listed on the Tunisian Stock Exchange over the period 2005-2010. The study is made with reference to different theories of capital structure, namely the trade-off, pecking order and market timing theories with focusing on the impact of market imperfections on debt ratio. Both static and dynamic panel data regressions are performed. The empirical results reveal that firm-specific factors such as firm size and profitability influence capital structure choice in Tunisia, while no meaningful effect is detected for growth opportunities. Our results also show that Tunisian listed companies adjust towards a target debt ratio. The adjustment appears to be slow on the Tunisian market because of high adjustment costs.
\end{abstract}

Keywords: capital structure, trade-off theory, pecking order theory, market timing theory, target debt ratio, adjustment costs, panel data

\section{Introduction}

Capital structure is the mix of equity and debt that a company uses for its financing. Its determination is one of the most difficult decisions for managers. Indeed, each source of financing has its advantages and disadvantages. Choosing a combination of bank loans, bonds, and equity is not evident. In the words of Myers (1984), it is a puzzle. Thus, a large body of literature has focused on the determinants of capital structure. However, empirical evidences do not lead to clear conclusions due to the contradiction of empirical results for the different variables.

Most previous studies of the determinants of capital structure have tried to explain leverage by a set of factors limited to a static approach. However, the observed leverage may deviate from the optimal level in the presence of adjustment costs. Thus, some studies enrich the analysis by using a dynamic approach. The recognition of the importance of using a dynamic approach to study capital structure is not new. In fact, this approach was used for the first time by Taggart (1977) and Jalilvand and Harris (1984) who show the existence of an adjustment process towards a target debt level for U.S. corporations. Later, different models for capital structure dynamics were developed for several countries. We can cite Ozkan (2001) for the U.K., Heshmati (2001) for Swedish firms, Miguel and Pindado (2001) for Spanish companies and Gaud et al. (2005) for the Swiss market. We also note that capital structure adjustment is among the new debated issues. In fact, recent studies have focused on it (Hovakimian \& Li, 2011; McMillan \& Camara, 2012; Oztekin \& Flannery, 2012; Dang et al., 2014).

Moreover, we notice the scarcity of studies on emerging markets. Prior researches have almost focused on capital structure in some developed countries. They have recently started looking at the capital structure behavior of companies operating in emerging markets. These markets have different characteristics compared to developed ones which may affect capital structure choice.

Particularly in Tunisia, the financing is mainly based on the banking system. Like most of the emerging countries, it is a bank-based economy rather than a market-based economy. Faced with globalization, Tunisian firms are involved in the problem of choosing an optimal capital structure to deal with the changing environment.

By using Tunisian data, we seek to answer the following question: What are the determinants of capital structure? More specifically, we try to answer these inquiries: (i) What are the factors that explain the financing behavior of Tunisian listed firms? (ii) Is there an adjustment process of capital structure towards a target or optimal debt level? (iii) How can we characterize the speed of adjustment? 
The aim of this article is to shed light on the determinants of capital structure for companies listed on the Tunisian Stock Exchange. We use both static and dynamic panel data models to confront the theoretical and empirical results in the literature with the Tunisian market, study the dynamic behavior of debt and test the existence of an adjustment process towards a target debt level.

Our contribution is thus twofold. First, we add to the existent literature by focusing on the determinant factors of capital structure of an emerging country, namely Tunisia. In fact, studying the Tunisian case may be interesting in terms of policy recommendations for this country and other emerging countries presenting similar features such as bank-oriented financial systems and relatively small capital markets. Second, this paper contributes to the relatively limited literature on the dynamics of capital structure. It checks out the existence of an adjustment process towards a target leverage in the Tunisian market.

The rest of this paper is organized as follows. Section 2 includes a review of the literature. Section 3 describes the data and methodology. The results of the empirical research and their interpretation are given in Section 4. Section 5 concludes.

\section{Literature Review}

The study of Modigliani and Miller (1958) is considered as the cornerstone of capital structure theory. It supports capital structure irrelevance in perfect capital markets. It also shows the independence of investment and financing decisions. These results have been subject to many critics because of unrealistic assumptions. Thus, subsequent works take into account market imperfections. Introducing market imperfections such as taxation, bankruptcy costs, transaction costs, information asymmetry and agency costs has contributed to the explanation of capital structure choice.

\subsection{Aspects of Capital Structure Related to Tax and Bankruptcy Costs}

Modigliani and Miller (1963) take into account corporate tax. They show that companies prefer debt to equity financing in order to benefit from tax deductibility of interest. Thus, the value of the leveraged company is maximized thanks to tax benefits. However, subsequent studies question this result.

Miller (1977) shows that Modigliani and Miller (1963) overestimate tax advantage of debt and neglect personal taxation. Taking into account both corporate and personal tax allows him to conclude that debt is neutral on firm value. Moreover, De Angelo and Masulis (1980) point out that non-debt tax shields derived from investment credit tax, depreciation and amortization deductions reduce firms' use of debt. They suggest that these are considered as substitutes to debt tax shields. Finally, Scott (1977) argues that bankruptcy costs also limit the benefit of potential interest tax shields and limit borrowing consequently.

\subsection{Aspects of Capital Structure Related to Information Asymmetry}

The determinants of capital structure may also be explained in the context of information asymmetry from the perspective of agency theory and signaling theory.

\subsubsection{Agency Theory}

In an agency relationship, one party (principal) appoints another party (agent) to act on its behalf. Information asymmetry is at the core of agency theory. In fact, the agent holding more information may have an incentive to act in his own interest and not that of the principal. This situation generates conflicts of interest.

Several studies suggest that capital structure is determined by agency costs due to conflicts of interest. Jensen and Meckling (1976) identify two types of conflicts: conflicts between shareholders and managers and conflicts between shareholders and debtholders.

According to Jensen and Meckling (1976), conflicts between shareholders and managers arise because managers do not own the total of capital. Thus, they can only get a fraction of the gain from their profit enhancement activities, but they have to bear all the consequences of their management. These conflicts can take different forms. First, managers have an incentive to invest less effort in managing the firm and to get more perquisites. In this case, issuing debt helps to mitigate this problem by committing managers to paying out free cash flow in debt repayment. Second, managers often prefer short-term projects which improve their reputation rather than more profitable long-term projects. Finally, the problem of overinvestment that arises when managers enlarge firms beyond the optimal size to enjoy the benefit of control instead of working for shareholders' interest by maximizing firm's value (Jensen, 1986).

Conflicts of interest between shareholders and debtholders arise because debt contract gives shareholders an incentive to invest suboptimally. Underinvestment problem occurs when shareholders skip new growth opportunities because most of the profits will be attributed to debt repayment (Myers, 1977). Debt also gives 
shareholders the incentive to invest in risky projects because of their high return. In case of failure, debtholders bear the consequences because of shareholders' limited liability. This is called the problem of asset-substitution which is an agency cost of debt financing (Jensen \& Meckling, 1976).

Hence, in the presence of asymmetric information, the use of debt may either cause or mitigate agency costs. Jensen and Meckling (1976) argue that an optimal capital structure can be obtained by trading-off the benefit of debt against the agency cost of debt.

\subsubsection{Signaling Theory}

The main idea of the theory of signals is the existence of imperfect information that is not shared equitably between insiders and outsiders. Capital structure can be used as a means to inform potential funders about the true value of the company in presence of asymmetric information.

Leland and Pyle (1977) present the signaling by the share of capital held by the entrepreneur. They consider the case of an entrepreneur who does not have the necessary funds to finance his investment project which he knows the potential revenue. They note that he may indicate the quality of the project to funders through his participation in the capital of the project. Thus, they show that the value of the firm is positively related to the participation of the manager-shareholder in the capital. The share of capital that he holds takes an informative aspect for potential investors.

Ross (1977) introduces the signaling by the debt ratio. He shows that the value of the company increases with its leverage. Thus, the use of debt is a good signal to investors because they presume that the company has good development prospects, otherwise it would have rejected debt. This encourages investors to be involved in financing the firm.

\subsection{Capital Structure Theories}

There are three main theoretical frameworks of reference for studying the financing behavior of companies; namely the trade-off, pecking order and market timing theories.

\subsubsection{Trade-Off Theory}

This theory states that the choice of debt ratio, which often summarizes the financial structure, results from a trade-off between tax advantage of debt and bankruptcy costs. This framework is known as the static trade-off theory.

Some authors extend this framework and develop the dynamic trade-off theory. It proposes that companies may deviate from their target debt level because of adjustment costs which are formed by the costs of issuing debt or equity, information asymmetry costs and financial constraints imposed by laws and regulations. Thus, they adjust their debt levels partially to reach a target ratio. In this context, we can cite Taggart (1977), March (1982), Jalilvand and Harris (1984) and Fischer et al. (1989) who were the first to demonstrate empirically the existence of a partial adjustment process of capital structure to a long-run target debt ratio. In Fact, Jalilvand and Harris (1984) note that for cost constraints due to market imperfections, firms do not fully adjust their capital structures to target structures. It is a partial adjustment.

In addition, Heshmati (2001) develops a dynamic model of financial structure adjustment towards a target level of debt based on a sample of Swedish micro and small enterprises. This study shows that the adjustment is very slow. The author argues that the costs of deviating from optimal leverage are not large enough to motivate costly external capital market transactions. Instead, leverage is slowly modified by means of internal financing sources. In the same vein, according to Ozkan (2001) the adjustment process of capital structure can be considered as the result of a trade-off between transaction costs caused by the movement towards a target leverage and the cost of being in disequilibrium.

Moreover, Miguel and Pindado (2001) analyze the determinants of capital structure using a sample of non-financial Spanish firms. They show that firms bear important transaction costs when they decide to adjust their leverage to the target level. Thus, the adjustment is not automatic in the presence of transaction costs. These costs are lower in the Spanish market due to the higher percentage of private debt compared to the American market. In fact, according to these authors private debt implies lower adjustment costs than public debt. This allows Spanish firms to adjust their capital structures to targets more easily.

\subsubsection{Pecking Order Theory}

This theory is introduced by Myers (1984) and modeled by Myers and Majluf (1984). It states that the choice between different sources of financing is determined by their information asymmetry level. In fact, these authors show that, under information asymmetry, firms' financing choice follows a hierarchical order which primary 
purpose is to maximize shareholders' wealth avoiding the costs associated to information asymmetry. The company prefers internal to external financing and debt to equity.

Thus, to finance its investments, it gives priority to self-financing. If this capacity is exhausted, it uses debt starting with the least risky one (bank debt), then the riskier (bonds and convertible bonds). Issuing equity is done at last resort because it is more subject to information asymmetry.

\subsubsection{Market Timing Theory}

This theory suggests that the choice of corporate financing follows a timing behavior. Thus, the capital structure depends on the stock market performance and the bond market conditions. Companies issue equity when their market values are high and repurchase equity when their market values are falling. The theory of market timing is mainly developed by Baker and Wurgler (2002). Several studies demonstrate empirically the financing behavior as described by this theory such as Welch (2004) and Huang and Ritter (2005).

The market timing theory has enriched the analysis of capital structure by identifying other factors that may explain the choice of financial structure such as interest rate behavior, stock market performance (Frank \& Goyal, 2003) and variation in the shares' prices (Welch, 2004).

\section{Data and Methodology}

\subsection{Sample Selection}

The aim of this paper is to study the determinants of capital structure for Tunisian listed firms. As in many studies of capital structure (Rajan \& Zingales, 1995; Drobetz \& Wanzenried, 2006; Hovakimian \& Li, 2011...), we exclude financial institutions and insurance companies from the sample because of their atypical financing behavior as it is subject to specific rules and regulations. Thus, starting with the 56 companies listed on the Tunisian Stock Exchange at the end of 2010, we exclude 24 financial firms detailed as follows: 11 banks, 4 insurance companies, 6 leasing companies, 2 investment funds and 1 venture capital company. The resulting sample consists of 32 non-financial companies. The period of study covers six years, from 2005 to 2010. It is an unbalanced panel given that there are companies that become listed during the period of study. The number of companies observed per year is given in Table 1. Data is collected from the Tunisian Stock exchange website using annual reports of statutory auditors on financial statements.

Table 1. Number of companies observed per year

\begin{tabular}{cc}
\hline Year & Number of companies \\
\hline 2005 & 22 \\
2006 & 26 \\
2007 & 27 \\
2008 & 29 \\
2009 & 31 \\
2010 & 32 \\
Total & 167 observations \\
\hline
\end{tabular}

\subsection{The Models}

\subsubsection{Static Model}

To investigate the determinants of capital structure we adopt the following static model:

$$
\mathrm{L}_{\mathrm{it}}=\alpha_{\mathrm{k}} \mathrm{X}_{\mathrm{it}}+\varepsilon_{\mathrm{it}}
$$

Where $\mathrm{L}_{\mathrm{it}}$ is the dependent variable, $\mathrm{i}=1 \ldots, 32, \mathrm{t}=2005 \ldots, 2010, \mathrm{X}_{\mathrm{it}}$ is the vector of explanatory variables, $\alpha$ is the vector of parameters to estimate, $\mathrm{k}$ is the number of explanatory variables and $\varepsilon_{\mathrm{it}}$ is the error term.

\subsubsection{Dependent Variable}

Studies on the determinants of capital structure often attempt to explain the level of debt of the company. However, different measures are used. Heshmati (2001) adopts the ratio of debt to the sum of debt and equity in book values, while Rajan and Zingales (1995) and Hovakimian and Li (2011) employ the ratio of total debt to assets as indicators of leverage.

Some works, such as March (1982) and Titman and Wessels (1988), disaggregate total debt into long term, short term and convertible debt. In this study, we will not perform this decomposition. We focus instead on the level of 
total debt, following Ferri and Jones (1979). These authors use the ratio of total debt to total assets and justify this choice by the conceptual simplicity and the ability of this ratio to completely reflect a company's total reliance on borrowed funds.

In this paper, to measure the company's leverage, we retain the book total debt ratio defined as the sum of long-term and short-term debts scaled by the book value of total assets, as in many previous studies of capital structure (Ferri \& Jones, 1979; Rajan \& Zingales, 1995; Gaud et al., 2005; Hovakimian \& Li, 2011; Oztekin \& Flannery, 2012).

\subsubsection{Independent Variables, Measures and Hypotheses}

In our empirical analysis we retain the variables that have been widely used in earlier studies of capital structure. We focus on five firm-specific variables which are: firm size, growth opportunities, tangibility, profitability and non-debt tax shields. In addition, we introduce a macroeconomic variable which is the interest rate.

We present the predictions of trade-off, pecking order and market timing theories for these variables. We also discuss their effects in the context of information asymmetry and agency costs as well as financial distress and signaling theories.

Firm size (Size): Many studies consider that the size of the company is a key factor in the choice of its capital structure. However, its effect remains controversial.

Within a bankruptcy costs' approach, Warner (1977) stipulates that leverage increases with size. Rajan and Zingales (1995) suggest that size may be an inverse proxy for the probability of bankruptcy. In fact, large firms are more diversified and have therefore more stable cash flow compared to smaller ones.

The pecking order theory, where capital structure choice depends on information asymmetry, predicts however a negative correlation between size and leverage. Rajan and Zingales (1995) argue that size may also be a proxy for information that outside investors have. Information asymmetry is lower for larger firms, which increases their preference for equity relative to debt.

Different measures have been used for the firm size. Heshmati (2001) uses the number of employees while Jalilvand and Harris (1984) and Hovakimian and Li (2011) use the natural logarithm of total assets. Rajan and Zingales (1995) suggest the logarithm of net sales. Titman and Wessel (1988) also use the natural logarithm of sales as well as the quit rate.

Like Titman and Wessels (1988), Rajan and Zingales (1995), Ozkan (2001) and Drobetz and Wanzenried (2006), we use the natural logarithm of sales as a measure of the firm size.

Referring to Rajan and Zingales (1995) and Warner (1977), we pose the following hypothesis:

Hypothesis 1: the firm size is positively correlated with debt.

Growth opportunities (MTB): Most of the previous studies estimate a significant effect of growth opportunities on leverage. Theories provide different explanations for this effect.

According to the agency theory, Jensen and Meckling (1976) show that debt encourages shareholders to invest suboptimally. Thus, indebted firms' shareholders tend to choose very risky projects in order to maximize their profit and bear the risk to creditors who will be therefore reticent to finance new investment opportunities. This implies a negative relationship between debt and growth options.

Myers (1977) confirms this negative correlation. Indeed, he considers that highly leveraged firms are more likely to miss growth opportunities. Thus, companies that anticipate important future growth should use more equity financing. The negative relationship between growth opportunities and debt is confirmed by several empirical studies, including Rajan and Zingales (1995) and Heshmati (2001).

Nevertheless, from the perspective of pecking order theory (Myers \& Majluf, 1984), companies with significant growth options rely primarily on debt as it represents the source of external financing that is less subject to information asymmetry. This suggests a positive correlation between the level of debt and the presence of growth opportunities.

According to Harris and Raviv (1991), the market to book ratio (defined as the market value of equity to its book value) is often used as a measure of growth opportunities. Other measures are used such as the growth rate of assets (Heshmati, 2001), the ratio of research and development spending to turnover, and the ratio of investment expenditure to total assets (Titman \& Wessels, 1988). Finally, Myers (1977) and Rajan and Zingales (1995) employ another market to book ratio defined as the market value of assets to their book value.

In this study, we use the market to book ratio defined as market value of equity over book value of equity as a 
measure of firm's growth opportunities, as suggested by Harris and Raviv (1991).

Based on the theoretical considerations of Myers (1977) and Jensen and Meckling (1976), and the empirical results of Rajan and Zingales (1995) and Heshmati (2001), our assumption is as follows:

Hypothesis 2: the variable "growth opportunities" is negatively correlated with debt ratio.

Tangibility (Tang): Capital structure theories suggest that the type of assets held by the company affects its financial structure. In fact, tangible assets provide more guarantees to lenders since they are less subject to information asymmetry and they lose less of their value in case of liquidation (compared to intangible assets). Scott (1977) notes that firms can borrow at lower rates if their debt is secured by tangible assets.

Moreover, Myers and Majluf (1984) show that there are costs associated with debt issuance in presence of information asymmetry. These costs can be avoided by issuing debt guaranteed by assets having a known value. Titman and Wessels (1988) also confirm that companies with more assets that are likely to be used as collateral may contract more debt.

Under the agency theory, specifically the conflicts of interest between shareholders and creditors, Jensen and Meckling (1976) and Myers (1977) note that the shareholders of indebted firms have an incentive to invest suboptimally and expropriate creditors' wealth. However, if the debt is secured, the company will limit the use of borrowed funds for a specific project. Concerning the conflicts of interest between shareholders and managers, Grossman and Hart (1982) suggest that a high level of debt reduces managers' overspending and tendency to maximize their own perquisites. It is the disciplinary role of debt. Furthermore, a highly leveraged firm is always subject to close monitoring by creditors (especially banks). This supervision will be more costly for companies with few assets that can be used as collateral. These companies may have a high level of debt to control managers. This suggests an inverse relationship between debt and tangibility.

To measure the effect of assets' tangibility, Titman and Wessels (1988) use two ratios: the ratio of intangible assets to total assets and the ratio of tangible assets to total assets which are, respectively, negatively and positively correlated with debt. Rajan and Zingales (1995) and Heshmati (2001) use the ratio of fixed assets to total assets and find that it is significantly and positively correlated with leverage.

In this paper, we retain the proxy suggested by Rajan and Zingales (1995), Heshmati (2001) and Joeveer (2013) which is the ratio of fixed assets to total book assets.

Hypothesis 3: we expect a positive relationship between assets' tangibility and leverage.

Profitability (Prof): In the pecking order theory, Myers and Majluf (1984) note that companies prefer internal to external financing. Profitable companies can rely more on self-financing, which suggests a negative relationship between leverage and profitability.

However, according to the signaling theory Ross (1977) shows that in the presence of information asymmetry profitable firms can signal their quality through debt. Hence, there is a positive relationship between leverage and profitability.

From the perspective of agency theory, Jensen and Meckling (1976) and Jensen (1986) consider debt as a discipline device that controls managers by forcing them to use the surplus of cash flow in repaying debt instead of consuming more perquisites. This suggests a positive correlation between leverage and profitability.

Titman and Wessels (1988) use two ratios as indicators of profitability: operating income reported to turnover and operating income to total assets. Heshmati (2001) uses the ratio of net income to total assets and finds a significant negative relation between leverage and firm profitability.

In this research, we retain the ratio of operating result to turnover as a proxy of the firm profitability as suggested by Titman and Wessels (1988).

Hypothesis 4: we assume that the profitability is negatively related to debt level (Myers \& Majluf, 1984).

Non-debt tax shields (NDTS): Since the study of Modigliani and Miller (1963), attention has been paid to tax as a determinant of capital structure. This study considers that the main motivation of debt is taking advantage of debt tax deductions.

However, under the trade-off theory, De Angelo and Masulis (1980) note that companies that benefit from significant tax deductions not related to debt (such as those for depreciations) give less importance to the tax advantage of debt and get less indebted consequently.

Several measures have been proposed in the literature for non-debt tax shields. Bradley et al. (1984) use the depreciation and amortization plus investment tax credit, while Wald (1999) retains the depreciation of tangible 
assets. Finally, Heshmati (2001) retains the ratio of depreciation of total assets.

In this study, we imitate Titman and Wessels (1988), Ozkan (2001) and Fama and French (2002) and we use the ratio of depreciation and amortization to total assets as a measure of non-debt tax shields.

Hypothesis 5: we expect a negative relationship between non-debt tax shields and leverage (De Angelo \& Masulis, 1980).

Interest rate (IR): According to the market timing theory, the increase of interest rate leads to a reduction in debt since managers avoid the use of debt when interest rates are high. This suggests a negative correlation between interest rate and leverage (Frank \& Goyal, 2003).

We suggest using the money market rate given that the borrowing rates are generally indexed on it (Fakhfakh \& Ben Atitallah, 2006). We consider the rate of December of each year of the study period.

Hypothesis 6: we assume a negative link between interest rate and debt.

Table 2. Measures of variables and predicted signs

\begin{tabular}{|c|c|c|}
\hline Variables & Retained measures & Predicted signs \\
\hline Book leverage $\left(\mathrm{L}_{\mathrm{it}}\right)$ & $($ Long-term debt + Short-term debt $) \quad /$ Total assets & Dependent variable \\
\hline Firm size (Size) & Natural logarithm of net sales & + \\
\hline Growth opportunities (MTB) & Market value of equity / Book value of equity & - \\
\hline Tangibility (Tang) & Fixed assets / Total assets & + \\
\hline Profitability (Prof) & Operating result / Turnover & - \\
\hline Non-debt tax shields (NDTS) & (Depreciation + Amortization) $/$ Total assets & - \\
\hline Interest rate (IR) & Money market rate & - \\
\hline
\end{tabular}

\subsubsection{Dynamic Model}

The static approach does not capture adjustments in debt ratios. Consequently, we need to use a dynamic approach. Under ideal conditions and in the absence of adjustment costs, the observed leverage for a firm $i$ at time $\mathrm{t}$ must be equal to the target (optimal) leverage: $L_{i t}=L_{i t}{ }^{*}$.

Where $\mathrm{L}_{\mathrm{it}}$ is the observed leverage for firm $\mathrm{i}$ at time $\mathrm{t}$ and $\mathrm{L}_{\mathrm{it}}{ }^{*}$ is the target leverage.

The dynamic approach implies that the change in leverage from the previous to the current period must be exactly equal to the change needed for the company to reach the target leverage at time $t$ :

$$
L_{i t}-L_{i t-1}=L_{i t}{ }^{*}-L_{i t-1}
$$

Where $\mathrm{L}_{\mathrm{it}-1}$ is the observed leverage at time $\mathrm{t}-1$.

However, if adjustments are costly, companies may adjust their leverage partially. Partial adjustment is represented as follows:

$$
\left(L_{i t}-L_{i t-1}\right)=\delta\left(L_{i t}{ }^{*}-L_{i t-1}\right)
$$

Where $\delta$ is the speed of adjustment towards the target debt ratio. With $0<\delta<1$.

Based on Drobetz and Wanzenried (2006) and Heshmati (2001), we have:

If $\delta=0$ : there is no move towards the target debt ratio because adjustment costs are too high.

If $\delta=1$ : the company adjusts completely to the target leverage and adjustment costs are zero.

If $\delta<1$ : there is a partial adjustment, because it is costly.

Since the value of target leverage $\mathrm{L}_{\mathrm{it}}{ }^{*}$ is not observable, we follow Gaud et al. (2005) as well as Drobetz and Wanzenried (2006) and estimate it from equation (3):

$$
\mathrm{L}_{\mathrm{it}}^{*}=\alpha_{\mathrm{k}} \mathrm{X}_{\mathrm{it}}+\varepsilon_{\mathrm{it}}
$$

Thus, we estimate target debt ratio as the fitted value from the regression of observed debt ratios on the set of predefined variables.

Once developed, equation (4) becomes:

$$
\mathrm{L}_{\mathrm{it}}=(1-\delta) \mathrm{L}_{\mathrm{it}-1}+\delta \alpha_{\mathrm{k}} \mathrm{X}_{\mathrm{it}}+\varepsilon_{\mathrm{it}}
$$

Where $\delta$ is the adjustment speed and $(1-\delta)$ is the adjustment cost. 
Equation (4) represents the dynamic regression model.

\section{Empirical Results and Discussion}

We present the results for the determinants of leverage with static and dynamic approaches and interpret their implications.

\subsection{Static Model}

Table 3 shows correlations between the different variables of our model. It reveals that correlations between the explanatory variables are low. Therefore, there is no multicolinearity problem and we keep all predefined variables in the model.

Table 3. Correlation matrix

\begin{tabular}{lccccccc}
\hline Variables & $\mathrm{L}_{\text {it }}$ & Size & MTB & Tang & Prof & NDTS & IR \\
\hline $\mathrm{L}_{\text {it }}$ & 1.0000 & & & & & & \\
Size & 0.0891 & 1.0000 & & & & & \\
MTB & -0.1090 & 0.1078 & 1.0000 & & & & \\
Tang & 0.3276 & -0.2630 & -0.1239 & 1.0000 & & & \\
Prof & -0.1739 & -0.0582 & -0.3096 & 0.0231 & 1.0000 & & \\
NDTS & 0.0203 & -0.1322 & -0.0661 & 0.1819 & 0.0066 & 1.0000 & \\
IR & -0.0045 & -0.0762 & -0.0499 & 0.0281 & -0.0197 & 0.0913 & 1.0000 \\
\hline
\end{tabular}

Table 4 provides summary statistics of the dependent and independent variables. It shows that the minimum and maximum levels of debt are respectively 0 and 1.51 with an average of 0.2 .

Table 4. Summary statistics

\begin{tabular}{lccccc}
\hline Variables & Observations & Mean & Standard deviation & Min & Max \\
\hline $\mathrm{L}_{\text {it }}$ & 167 & 0.2 & 0.24 & 0 & 1.51 \\
Size & 166 & 17.58 & 1.24 & 14.32 & 20.77 \\
MTB & 167 & 2.27 & 2.89 & -1.53 & 26.04 \\
Tang & 167 & 0.48 & 0.17 & 0.0012 & 0.81 \\
Prof & 167 & 0.06 & 0.63 & -7.34 & 1.24 \\
NDTS & 167 & 0.11 & 0.53 & 0 & 5.06 \\
IR & 167 & 0.049 & 0.004 & 0.0418 & 0.0533 \\
\hline
\end{tabular}

In order to choose the suitable estimation procedure, we start by checking data homogeneity.

Constants homogeneity test is a Fischer test under the null hypothesis that all the coefficients specific to each term are equal and constant. It detects the presence of firm-specific effects. Under the null hypothesis, we assume the absence of firm-specific effects and the homogeneity of data. Otherwise, we accept the presence of heterogeneity. The null hypothesis is rejected if $p$-value $<5 \%$.

This test reveals the existence of a problem of heterogeneity since $F(31,128)=30.88$ and its p-value is equal to 0 (less than 5\%). Hence, the procedure of Ordinary Least Squares (OLS) is biased.

In panel econometrics, two models take into account heterogeneity: the fixed effects model and the random effects model. The random effects model differs by decomposing the error term into two components:

$$
\varepsilon_{\text {it }}=\mu_{i}+v_{i t} \text {. }
$$

Where $\mu_{\mathrm{i}}$ : random variable specific to the company, it is constant over time and $v_{i t}$ : new term of error.

The choice between the fixed effects model and the random effects model is based on Hausman (1978) test. Hausman test is asymptotically distributed as chi-square under the null hypothesis of the absence correlation between explanatory variables and the error term $\mu_{\mathrm{i}}$. The acceptance of the null hypothesis implies the use of random effects model. In the opposite case, the fixed effects model would be more appropriate.

The Hausman test results confirm the rejection of the null hypothesis and the selection of the fixed effects model ( $p$-value $=0<5 \%$ ). Thus, the static model is as follows: 


$$
\mathrm{L}_{\mathrm{it}}=\alpha_{0 \mathrm{i}}+\alpha_{1} \text { Size }_{\mathrm{it}}+\alpha_{2} \text { MTB }_{\mathrm{it}}+\alpha_{3} \text { Tang }_{\mathrm{it}}+\alpha_{4} \operatorname{Prof}_{\mathrm{it}}+\alpha_{5} \text { NDTS }_{\mathrm{it}}+\alpha_{6} \mathrm{IR}_{\mathrm{t}}+\varepsilon_{\mathrm{it}}
$$

Table 5 provides the estimation results for the static model (4).

Table 5. Estimation results for the static model

\begin{tabular}{lll}
\hline Explanatory variables and other statistics & Fixed effects model & Random effects model \\
\hline Size & 0.08 & 0.03 \\
& $(2.63)^{* * *}$ & $(1.56)$ \\
Growth opportunities & -0.00041 & -0.00095 \\
& $(-0.13)$ & $(-0.28)$ \\
Tangibility & -0.0158 & 0.123 \\
& $(-0.17)$ & $(1.37)$ \\
Profitability & 0.0395 & 0.0306 \\
& $(3.19)^{* * *}$ & $(2.21)^{* *}$ \\
Non-debt tax shields & -0.0139 & -0.0144 \\
& $(-0.99)$ & $(-0.92)$ \\
Interest rate & -0.0642 & -0.7387 \\
& $(-0.04)$ & $(-0.38)$ \\
Constant & -1.194 & -0.371 \\
$\mathrm{R}^{2}$ Within & $(-2.08)^{* *}$ & $(-0.96)$ \\
$\mathrm{R}^{2}$ Between & 0.1487 & 0.1136 \\
$\mathrm{R}^{2}$ Overall & 0.0057 & 0.0032 \\
Homogeneity test & 0.0012 & 0.0259 \\
p-value & 30.88 & \\
Hausman test & 0 & \\
p-value & 29.57 & \\
Fischer test & 0 & \\
p-value & 3.73 & \\
Firms & 0.0019 & \\
Observations & 32 & \\
\hline
\end{tabular}

Note. T-statistics are in parentheses;**SStatistically significant at the $1 \%$ level; **Statistically significant at the $5 \%$ level; ${ }^{*}$ Statistically significant at the $10 \%$ level.

We first interpret the coefficients of determination (R-squared). For the fixed effects model, the most important coefficient of determination is the within $R^{2}$ since it reflects the share of intra-individual variability of the dependent variable explained by explanatory variables. According to the results, only $14.87 \%$ of intra-individual variability of the endogenous variable is explained by exogenous variables. Moreover, the between $R^{2}$, which reflects the contribution of the fixed effects in the model, is equal to $0.57 \%$. Finally, the overall $R^{2}$, giving a general idea of the goodness of fit equals $0.12 \%$. This low value indicates a poor fit of the model. However, it does not allow assessing the overall significance of the model (4). The latter is tested using Fischer overall significance test.

We have $F(6,128)=3.73$ and the corresponding p-value is equal to 0.0019 (inferior to $5 \%$ ). We conclude that, overall, the explanatory variables explain firms' debt level.

After interpreting the overall significance of the model, we move to the study of explanatory variables significance one by one as well as their signs. The estimation results of the static model reveal that only size and profitability variables are significant at the $1 \%$ level, the rest of explanatory variables are insignificant.

Firm size (Size): The estimation results of the static model show that the impact of size on debt ratio is positive and significant at the $1 \%$ level. Hence, firm size is an important determinant of leverage for Tunisian listed companies and large firms have more debt. This result seems to confirm, on the one hand, the hypothesis advanced by Warner (1977) and Rajan and Zingales (1995) that the size is an inverse proxy for the probability of bankruptcy. On the other hand, it confirms the fact that larger firms benefit from more favorable debt conditions (Ferri \& Jones, 1979).

Growth opportunities (MTB): This variable is associated with an insignificant negative coefficient. Hence, 
growth opportunities do not seem to have an impact on the leverage of Tunisian listed companies.

Tangibility (Tang): The estimated coefficient of this variable is negative and insignificant. Thus, according to the estimation results of the static model, firms' assets structure has no impact on leverage. This result seems to disprove the hypothesis of the use of tangible assets as collateral. The non-significance of this variable is surprising in the Tunisian market characterized mainly by the use of bank financing to the detriment of equity financing. Indeed, banks usually require collateral.

Profitability (Prof): The coefficient of profitability is positive and significant at the $1 \%$ level. The positive effect of this variable on debt ratio seems to confirm the agency theory, specifically the disciplinary role of debt (Jensen, 1986). Thus, Tunisian listed firms raise debt when profitability increases to monitor mangers. Moreover, this result supports the predictions of the signaling theory. In the presence of asymmetric information, listed profitable companies signal their quality by leveraging up. However, this result contradicts the predictions of the pecking order theory which states that profitable companies have significant cash flow that allows them to resort to internal financing and use less debt.

Non-debt tax shields (NDTS): The estimation results of the static model give a negative and insignificant coefficient. Therefore, non-debt tax shields have no effect on the leverage of the sample's firms.

Interest rate (IR): According to the estimation results, the interest rate has a negative and insignificant effect on debt ratio. This result leads to the conclusion that the debt behavior of Tunisian listed companies does not appear to follow the market timing theory.

\subsection{Dynamic Model}

We remind that the dynamic model has the following form:

$$
\mathrm{L}_{\mathrm{it}}=(1-\delta) \mathrm{L}_{\mathrm{it}-1}+\delta \alpha_{\mathrm{k}} \mathrm{X}_{\mathrm{it}}+\varepsilon_{\mathrm{it}}
$$

More explicitly, the dynamic regression model is as follows:

$$
\begin{aligned}
& \mathrm{L}_{\mathrm{it}}=\delta \alpha_{0 \mathrm{i}}+(1-\delta) \mathrm{L}_{\mathrm{it}-1}+\delta \alpha_{1} \operatorname{Size}_{\text {it }}+\delta \alpha_{2} \mathrm{MTB}_{\text {it }}+\delta \alpha_{3} \operatorname{Tang}_{\text {it }}+\delta \alpha_{4} \operatorname{Pr}_{\text {of }}+\delta \alpha_{5} \text { NDTS }_{\text {it }} \\
& +\delta \alpha_{6} \mathrm{IR}_{\mathrm{t}}+\varepsilon_{\mathrm{it}}
\end{aligned}
$$

Since this is a dynamic model, characterized by the presence of the lagged dependent variable $\mathrm{L}_{\mathrm{it}-1}$ as an explanatory variable, the standard econometric techniques (such as Ordinary Least Squares, fixed or random effects models) provide biased and inconsistent estimates because of the presence of a non exogenous independent variable. Indeed, the correlation between the latter and the error term makes estimators inconsistent. In this case, the Generalized Method of Moments (GMM) is the appropriate estimation method.

For this study, we use the first difference GMM estimator of Arellano and Bond (1991) which is used in prior works for the estimation of dynamic models of capital structure (Miguel \& Pindado, 2001; Gaud et al., 2005; Drobetz \& Wanzenried, 2006).

Dynamic panel data estimations, as developed by Arellano and Bond (1991), require two statistical tests to check for potential misspecification of the model:

Sargan (1958) test of over-identifying restrictions: this test is asymptotically distributed as a chi-square. It tests the validity of instrumental variables. Under the null hypothesis, we accept the absence of correlation between instruments and residuals and instruments are valid.

The validity of instruments is proven by the Sargan test for both one-step and two-step estimations with respective p-values of 0.2891 and 0.2544 , which are higher than the significance level of $5 \%$.

Serial correlation test: this test asymptotically follows a standard normal distribution $\mathrm{N}(0,1)$ under hypothesis of the lack of second-order autocorrelation of residuals. The p-values permit us to accept the null hypothesis.

Thus, these two tests allow us to conclude that the specification of our dynamic model is valid for the use of Arellano and Bond (1991) first difference GMM estimator.

Table 6 presents the estimation results for the dynamic model (5) as provided by the one-step and two-step estimators of Arellano and Bond. 
Table 6. Estimation results for the dynamic model

\begin{tabular}{lll}
\hline \multirow{2}{*}{ Explanatory variables and other statistics } & \multicolumn{2}{l}{ Arellano and Bond estimator } \\
& One-step & Two-step \\
\hline \multirow{2}{*}{$\mathrm{L}_{\text {it-1 }}$} & 0.367 & 0.43 \\
Size & $(1.81)^{*}$ & $(13.38)^{* * *}$ \\
& 0.061 & 0.064 \\
Growth opportunities & $(2.17)^{* *}$ & $(6.62)^{* * *}$ \\
& -0.002 & -0.00033 \\
Tangibility & $(-0.79)$ & $(-0.25)$ \\
& 0.075 & 0.114 \\
Profitability & $(0.78)$ & $(2.09)^{* *}$ \\
& -0.091 & -0.09 \\
Non-debt tax shields & $(-2.63)^{* * *}$ & $(-4.94)^{* * *}$ \\
& -0.023 & -0.023 \\
Interest rate & $(-1.8)^{*}$ & $(-18.8)^{* * *}$ \\
& 0.852 & 2.032 \\
Constant & $(0.45)$ & $(2.85)^{* * *}$ \\
Sargan Test & 0.005 & 0.0053 \\
p-value & $(1.08)$ & $(2.94)^{* * *}$ \\
First order autocorrelation test & 10.81 & 18.16 \\
p-value & 0.2891 & 0.2544 \\
Second order autocorrelation test & -2.23 & -1.92 \\
p-value & 0.0255 & 0.0542 \\
Firms & 0.13 & -0.13 \\
Observations & 0.8927 & 0.8972 \\
\end{tabular}

Note. t-statistics are in parentheses;***Statistically significant at the $1 \%$ level; **Statistically significant at the $5 \%$ level; $*$ Statistically significant at the $10 \%$ level.

The dynamic analysis allows us to study the financing behavior of Tunisian listed companies over time and to check the existence of adjustment costs. We note that the dynamic model causes a loss of observations as it is estimated in first differences and contains a lagged variable as an explanatory variable. Thus, our sample is reduced from 167 to 102 observations.

The estimation results of the dynamic model indicate that all explanatory variables are significant, except the variable "growth opportunities" (MTB). We notice that there are more significant explanatory variables for the dynamic analysis compared to the static one. In addition, the profitability variable (Prof) has changed its sign from the static to the dynamic model.

Speed and cost of adjustment: The speed of adjustment presented by the coefficient $\delta$ is inversely proportional to adjustment costs $(1-\delta)$ which represent the coefficient of the lagged leverage $\mathrm{L}_{\mathrm{it}-1}$.

The coefficient $(1-\delta)$ is positive and significant at the $10 \%$ level for the one-step estimator and at the $1 \%$ level for the two-step one. The relevance of lagged debt ratio $\mathrm{L}_{\mathrm{it}-1}$ confirms the existence of a dynamic adjustment process towards a target level. In fact, Tunisian listed companies have a target debt ratio to which they adjust partially in each period. This result also confirms the existence of adjustment costs on the Tunisian market. So, Tunisian firms bear adjustment costs when they decide to adjust their debt level of the previous period to the target level in the current period.

For the Tunisian market, adjustment costs presented by the coefficient $(1-\delta)$ amounted to 0.43 for the two-step estimations. This implies that the adjustment speed $\delta$ is equal to 0.57 .

Compared to other markets, these adjustment costs are higher than the Spanish market $(0.21$ in Miguel and Pindado (2001)), and even those in the U.S. (0.383 in Jalilvand and Harris (1984) and 0.41 in Shyam-Sunder and Myers (1999)). However, they are less than the adjustment costs recorded by Kremp et al. (1999) in the German and French markets $(0.47$ and 0.72 respectively). They are also lower than those in the U.K. as reported by 
Ozkan (2001) (0.43 to 0.48), as well as in the Swiss market (between 0.71 and 0.85 as reported by Gaud et al. (2005)).

Miguel and Pindado (2001) explain the low adjustment costs in the Spanish market (compared to the American market) by the importance of the ratio of private debt in Spanish firms. Public debt implies higher transaction costs, according to these authors. They conclude that the low level of development of the Spanish bond market allows firms to adjust more easily to the target structures using private debt. For our study, this explanation is not valid. Although the Tunisian bond market is not developed enough, we find that adjustment costs are high. This can be explained by the fact that Tunisian firms mostly rely on bank financing at the expense of capital markets. In fact, bank financing is expensive in Tunisia.

Moreover, Ozkan (2001) argues that the adjustment process is a trade-off between the adjustment costs of moving towards a target debt ratio and the costs of being in disequilibrium. Hence, we can conclude that Tunisian listed companies adjust to target leverages only when the benefits of adjusting to the target exceed the adjustment costs.

Size (Size): The one-step and two-step estimated coefficients related to this variable are positive and significant, respectively at the $5 \%$ and $1 \%$ levels. This result confirms that the debt ratio increases with the firm size and rejoined again the suggestion of Rajan and Zingales (1995) that the size can be considered as an inverse measure of the probability of bankruptcy.

Growth opportunities (MTB): The coefficients of this variable are negative and insignificant. This result reconfirms that growth opportunities are not relevant in capital structure choice for Tunisian listed firms.

Tangibility (Tang): According to the two-step estimator of Arellano and Bond, the tangibility of assets affects positively the debt ratio and the coefficient is significant at the $5 \%$ level. So, the debt ratio increases with the proportion of tangible assets in the company's total assets. This confirms the use of tangible assets as collateral for debt and the predictions of the trade-off theory. This result is logic on the Tunisian market where financing is based mainly on bank loans which generally require tangible guarantees.

Profitability (Prof): The negative and significant coefficients at the level of 1\% (for both one-step and two-step estimators) can be interpreted as favorable to the predictions of the pecking order theory. Indeed, this theory states that firms first exhaust their internal sources of financing before resorting to debt (Myers \& Majluf, 1984). Thus, according to the dynamic approach profitability is an important determinant of the leverage of Tunisian listed companies, and the more the firm is profitable, the less it uses debt financing. This result is consistent with the findings of Heshmati (2001) on the Swedish market and Drobetz and Wanzenried (2006) on the Swiss market, which provide significant and negative coefficients confirming the existence of a pecking order behavior. However, Fischer et al. (1989) and Gaud et al. (2005) argue that in the dynamic models based on the existence of a target leverage debt can easily be repaid thanks to extra cash provided by internal sources. This leads companies to have a pecking order behavior in the short term, despite the fact that they are increasing their debt ratios.

Non-debt tax shields (NDTS): The one-step and two-step estimated coefficients are negative and significant respectively at the $10 \%$ and $1 \%$ levels. The inverse relationship between leverage and the non-debt tax shields confirms the fact that this benefit is a substitute for debt which reduces the tax burden on firms (Titman $\&$ Wessels, 1988; Miguel \& Pindado, 2001). This result is consistent with the predictions of the trade-off theory.

Interest rate (IR): The two-step estimated coefficient associated with this variable is positive and statistically significant at the $1 \%$ level. The result contradicts the predictions of the market timing theory, which states that an increase in interest rates leads to a reduction of debt. Companies in our sample continue raising debt even when interest rates are increasing. We can thus conclude that the borrowing behavior of Tunisian listed firms does not follow a market timing behavior.

\section{Conclusion}

In this paper we attempt to explain the financing choice of Tunisian listed companies as well as its dynamic in the time. We develop a static model and a dynamic adjustment model to check the relevance of the predictions of different theories about the determinants of capital structure and its dynamics on the Tunisian market.

The estimation results of the static model give significant and positive relationships between leverage and the size of the company and its profitability. The result for firm size confirms the predictions of the bankruptcy theory that the size is an inverse measure of the probability of bankruptcy. Moreover, the positive effect of profitability confirms the agency theory and the disciplinary role of debt in the Tunisian market. In addition, it is consistent with the signaling theory as it suggests that debt is used by Tunisian listed firms as a device to signal 
their profitability. However, this result contradicts the predictions of the pecking order theory. The remaining variables are insignificant.

For the dynamic model, all variables are significant except "growth opportunities". The result for the size variable is the same as in the static model. The impact of profitability is negative confirming the existence of a pecking order behavior. The positive effect of assets' tangibility variable confirms the use of tangible assets as collateral for debt, which seems logic in the Tunisian market characterized by the important use of bank loans that typically require collateral. However, the positive effect of interest rate on leverage seems to refute the predictions of the market timing theory. In addition, we found a negative effect of non-debt tax shields. Finally, the estimation results of the dynamic model show the existence of a slow adjustment towards a target capital structure. The slowness is explained by the fact that companies in the sample bear relatively high adjustment costs compared to studies on other markets.

Like any research work, this study has some limits. First, the Tunisian stock market is very modest in terms of number of listed companies which justifies our small sample. Secondly, we find that the coefficients of determination are low for the regression model which indicates a poor linear fit.

Introducing aspects of behavioral finance such as overconfidence and optimism could be a new insight into the theory of capital structure. Further studies are also suggested to examine the impact of national culture and religion on capital structure choice.

\section{References}

Arellano, M., \& Bond, S. (1991). Some Tests of Specification for Panel Data: Monte Carlo Evidence and an Application to Employment Equations. Review of Economic Studies, 58, 277-297. http://dx.doi.org/10.2307/2297968

Baker, M. P., \& Wurgler, J. (2002). Market timing and capital structure. Journal of Finance, 5(1), 1-32. http://dx.doi.org/10.1111/1540-6261.00414

Bradley, M., Jarell, G., \& Kim, E. (1984). On the existence of an optimal capital structure. Journal of Finance, 39, 857-878. http://dx.doi.org/10.2307/2327950

Dang, V. A., Kim, M., \& Shin, Y. (2014). Asymmetric capital structure adjustments: New evidence from dynamic panel threshold models. Journal of Empirical Finance, 19(4), 465-482. http://dx.doi.org/10.1016/j.jempfin.2012.04.004

De Angelo, H., \& Masulis, R. (1980). Optimal Capital Structure under Corporate and Personal Taxation. Journal of Financial Economies, 8, 3-29. http://dx.doi.org/10.1016/0304-405X(80)90019-7

Drobetz, W., \& Wanzenried, G. (2006). What determines the speed of adjustment to the target capital structure? Applied Financial Economics, 16, 941-958. http://dx.doi.org/10.1080/09603100500426358

Fakhfakh, H., \& Ben Atitallah, R. (2006). Les déterminants de la structure du capital des firmes tunisiennes : une étude à travers la théorie de Market Timing. Actes $d u$ XXII $^{\text {ème }}$ congrès international de l'association française de financement (AFFI), Poitiers 26-27 Juin.

Fama, E. F., \& French, K. R. (2002). Testing trade-off and pecking order predictions about dividends and debt. Review of Financial Studies, 15, 1-33. http://dx.doi.org/10.1093/rfs/15.1.1

Ferri, M., \& Jones, W. (1979). Determinants of financial structure: A new methodological approach. Journal of Finance, 34, 631-644. http://dx.doi.org/10.1111/j.1540-6261.1979.tb02130.x

Fischer, E. R., Heinkel, \& Zechner, J. (1989). Dynamic Capital Structure Choice: Theory and Tests. Journal of Finance, 44, 19-40. http://dx.doi.org/ 10.1111/j.1540-6261.1989.tb02402.x

Flannery, M. J., \& Rangan, K. P. (2006). Partial adjustment toward target capital structures. Journal of Financial Economics, 79, 469-506. http://dx.doi.org/10.1016/j.jfineco.2005.03.004

Frank, M. Z., \& Goyal, V. K. (2003). Testing the pecking order theory of capital structure. Journal of Financial Economics, 67, 217-248. http://dx.doi.org/10.1016/S0304-405X(02)00252-0

Gaud, P., Jani, E., Hoesli, M., \& Bender, A. (2005). The capital structure of Swiss companies: An empirical analysis using dynamic panel data. European Financial Management, 11(1), 51-69. http://dx.doi.org/10.1111/j.1354-7798.2005.00275.x

Grossman, S. J., \& Hart, O. (1982). Corporate Financial Structure and Managerial Incentives. The Economics of Information and Uncertainty. Chicago: The University of Chicago Press. 
Harris, M., \& Raviv, A. (1991). The Theory of Capital Structure. The Journal of Finance, 46(1), 297-355. http://dx.doi.org/10.2307/2328697

Hausman, A. (1978). Specification tests in econometrics. Econometrica, 46, 1251-1271. http://dx.doi.org/10.2307/1913827

Heshmati, A. (2001). The Dynamics of Capital Structure: Evidence from Swedish Micro and Small Firms. Research in Banking and Finance, 2, 199-241.

Hovakimian, A., \& Li, G. (2011). In search of conclusive evidence: How to test for adjustment to target capital structure. Journal of Corporate Finance, 17(1), 33-44. http://dx.doi.org/10.1016/j.jcorpfin.2010.07.004

Huang, R., \& Ritter, J. R. (2005). Testing the market timing theory of capital structure. Journal of Financial and Quantitative Analysis, 1, 221-246. http://dx.doi.org/10.2139/ssrn.938564

Jalilvand, A., \& Harris, R. (1984). Corporate Behavior in Adjusting to Capital Structure and Dividend Targets: $\begin{array}{lllll}\text { An Econometric Study. Journal of Finance, } & 39,\end{array}$ http://dx.doi.org/10.1111/j.1540-6261.1984.tb03864.x

Jensen, M. (1986). Agency Costs of Free Cash Flow, Corporate Finance and Takeovers. American Economic Review, 76(2), 323-329. http://dx.doi.org/10.2139/ssrn.99580

Jensen, M., \& Meckling, W. (1976). Theory of the Firm: Managerial Behavior, Agency Costs and Ownership Structure. Journal of Financial Economies, 3, 305-360. http://dx.doi.org/10.1016/0304-405X(76)90026-X

Joeveer, K. (2013). Firm, country and macroeconomic determinants of capital structure: Evidence from transition economies. Journal of Comparative Economics, 41, 294-308. http://dx.doi.org/10.1016/j.jce.2012.05.001

Kremp, E., Stoss, E., \& Gerdesmeier, D. (1999). Estimation of a debt function: Evidence from French and German firm panel data. SSRN Working Paper.

Leland, H. E., \& Pyle, D. H. (1977). Informational, Asymmetries, Financial Structure, and Financial Intermediation. Journal of Finance, 32, 371-387. http://dx.doi.org/10.2307/2326770

Marsh, P. R. (1982). The Choice Between Equity and Debt: An Empirical Study. Journal of Finance, 1(3), 121-144. http://dx.doi.org/10.2307/2327121

McMillan, D. G., \& Camara, O. (2012). Dynamic capital structure adjustment: US MNCs \& DCs. Journal of Multinational Financial Management, 22(5), 278-301. http://dx.doi.org/10.1016/j.mulfin.2012.10.001

Miguel, A., \& Pindado, J. (2001). Determinants of capital structure: New evidence from Spanish panel data. Journal of Corporate Finance, 7, 77-99. http://dx.doi.org/10.1016/S0929-1199(00)00020-1

Miller, M. H. (1977). Debt and Taxes. Journal of Finance, 32, 261-75. http://dx.doi.org/10.2307/2326758

Modigliani, F., \& Miller, M. H. (1958). The cost of capital, corporate finance, and the theory of investment. American Economic Review, 48, 261-297.

Modigliani, F., \& Miller, M. H. (1963). Corporate Income Taxes and the Cost of Capital: A Correction. American Economic Review, 53(3), 433-443.

Myers, S. C. (1977). Determinants of corporate borrowing. Journal of Financial Economies, 5, 147-175. http://dx.doi.org/10.1016/0304-405X(77)90015-0

Myers, S. C. (1984). The capital structure puzzle. Journal of Finance, 34, 575-592. http://dx.doi.org/10.2307/2327916

Myers, S. C., \& Majluf, N. S. (1984). Corporate Financing and Investment Decisions when Firms have Informations that Investors do not have. Journal of Financial Economies, 13, 187-221. http://dx.doi.org/10.1016/0304-405X(84)90023-0

Ozkan, A. (2001). Determinants of capital structure and adjustment to long run target evidence from UK company panel data. Journal of Business Finance and Accounting, 28, 175-198. http://dx.doi.org/10.1111/1468-5957.00370

Oztekin, O., \& Flannery, M. J. (2012). Institutional determinants of capital structure adjustment speeds. Journal of Financial Economics, 103(1), 88-112. http://dx.doi.org/10.1016/j.jfineco.2011.08.014

Rajan, R. G., \& Zingales, L. (1995). What Do We Know about Capital Structure? Some Evidence from Internationa

Data.

Journal of

Finance,

50 ,

1421-1460. 
http://dx.doi.org/10.1111/j.1540-6261.1995.tb05184.x

Ross, S. A. (1977). The determination of Financial Structure: The Incentive Signaling Approach. Journal of Economies, 8, 23-40. http://dx.doi.org/10.2307/3003485

Sargan, J. D. (1958). The Estimation of Economic Relationship Using Instrumental Variables. Econometrica, 26, 393-415. http://dx.doi.org/10.2307/1907619

Scott, J. H. (1977). Bankruptcy, Secured Debt, and Optimal Capital Structure. Journal of Finance, 32(1), 1-19. http://dx.doi.org/10.2307/2326898

Shyam-Sunder, L., \& Myers, S. (1999). Testing Static Trade-Off against Pecking Order Models of Capital Structure. Journal of Financial Economics, 51, 219-244. http://dx.doi.org/10.1016/S0304-405X(98)00051-8

Taggart, R. A. (1977). A Model of Corporate Financing Decisions. Journal of Finance, 32, 1467-1484. http://dx.doi.org/10.2307/2326804

Titman, S., \& Wessels, R. (1988). The Determinants of Capital Structure Choice. Journal of Finance, 43, 1-20. http://dx.doi.org/10.1111/j.1540-6261.1988.tb02585.x

Wald, J. (1999). How Firm Characteristics Affect Capital Structure: An International Comparison. Journal of Financial Research, 22(2), 161-187. http://dx.doi.org/10.2307/2328319

Warner, J. (1977). Bankruptcy Costs: Some Evidence. Journal of Finance, 32, 337-347. http://dx.doi.org/10.2307/2326766

Welch, I. (2004). Capital Structure and Stock Returns. Journal of political economy, 112(1), 106-131. http://dx.doi.org/10.1086/379933

\section{Copyrights}

Copyright for this article is retained by the author(s), with first publication rights granted to the journal.

This is an open-access article distributed under the terms and conditions of the Creative Commons Attribution license (http://creativecommons.org/licenses/by/3.0/). 